\title{
Increase in efficiency of professionally applied physical training of pupils of 16-17 years old based on application of informational and methodical systems
}

\author{
Kashuba V.O. ${ }^{1 \mathrm{ABCDE}}$, Golovanova N.L. ${ }^{2 \mathrm{BCDE}}$ \\ ${ }^{1}$ Department of Biomechanics and Sports Metrology, National University of Physical Education \\ and Sport of Ukraine, Ukraine \\ ${ }^{2}$ Department of Innovation and Information Technologies in Physical Culture and Sports, National University of \\ Physical Education and Sport of Ukraine, Ukraine
}

Authors' Contribution: A - Study design; B - Data collection; C - Statistical analysis; D - Manuscript Preparation; E - Funds Collection.

\begin{abstract}
Purpose: $\quad$ to prove the technology aimed at the development of professionally applied physical qualities of future specialists of sewing industry with use of information technologies.

Material: $\quad$ girls of $16-17$ years old $(n=40)$ participated in the experiment. It was defined: level of physical activity of pupils; physical and mental working capacity.

Results: $\quad$ The developed technology included three stages: 1 st stage - 16 lessons; 2nd stage - 48 lessons; 3rd stage 16 lessons. It was detailed professionally applied physical qualities of future specialists of sewing industry taking into consideration the features of specialty. It was developed 4 blocks of physical exercises. Blocks include 14 different complexes for the practical application in different parts of trainings. The technology gives the opportunity to monitoring theoretical knowledge and physical abilities.

Conclusions: the recommended technology promotes: development of professionally significant physical qualities; increase in level of theoretical knowledge; formation of positive motivation of pupils to physical culture classes; preparation of harmonically developed and highly qualified specialists.

Keywords: $\quad$ professionally applied physical training, informational and methodical system, pupils of professional educational institutions.
\end{abstract}

\section{Introduction}

In the system of professional education a lot of factors influence on the formation of professionally applied skills and quality of study. Increases in academic load, irrational nutrition, and insufficient physical activity have negative effect. All this leads to overfatigue, decrease in functional and psychophysiological abilities of pupils [1, 2].

The special place in professional education of future specialists is taken by the professionally applied physical training (PAPT) [2, 3]. The author [3] implemented the systematization of specialists' fields of study at higher educational institutions. The author considers psychophysiological features of professional activity. It was selected six appropriate groups: data logical, extreme, creatively figurative, technical, naturally agrarian and communicative. In other researches was defined professionally important physical and psychophysical qualities characteristic of other specialties. Such researches could be basic of PAPT students' program of information logistic group of specialties. Application of the information technologies (IT) in practice of student's physical training $[3,4]$ give new opportunities for increase in efficiency of physical training process. IT can promote the organization of professionally applied physical training.

In recent years were conducted researches concerning problem of PAPT improvement in different educational institutions [1]. Physical culture classes in professional educational institutions are directed to the training of pupils for future professional activity [5, 6]. At the same time don't use all opportunities of physical training means (c) Kashuba V.O., Golovanova N.L., 2018 doi:10.15561/20755279.2018.0201 for pupils' preparation to the future work activity. The satisfaction of increase competition in sewing industry requires continuous increase in qualified personnel able to competently solve professional tasks [5].

Different authors [7-9] developed information systems for increase in efficiency of pedagogical process in physical training of pupils. It is determined insufficient information concerning implementation of the modern computer program into physical training process at professional educational institutions. Therefore this aspect is relevant and necessary.

The purpose of the research is to develop and to prove experimentally the technology of development of professionally applied physical qualities of future specialists of sewing industry with use of information technologies.

\section{Materials and methods}

Participants. Girls of 16-17 years old $(\mathrm{n}=40)$ participated in a research. They were divided into 2 groups: experimental $(n=20)$ and control $(n=20)$. Groups were divided by random choice and hadn't significant differences between indicators at the beginning of experiment.

Organization of a research. The research was conducted on the basis of the state educational institution "Balty vocational-technical agrarian school" (Balty city, Odessa region, Ukraine). Control group (CG) was studied according to the training program for professional educational institutions of physical culture. The program is recommended by Ministry of Education and Science of Ukraine (the letter of the Ministry of Education and 
Science of Ukraine from 22.07.2009, № 1/11-5948) [10]. Total quantity of lessons is 80 . According to the curriculum were conducted two 45 min lessons per a week. Ski preparation lessons were conducted $90 \mathrm{~min}$ per a week.

In experimental group (EG) girls were studied according to the developed technology which was integrated into the basic program of the state educational institution "Balty vocational-technical agrarian school".

The level of pupils' physical activity was determined according to the Fremingemsky study [11]. Calculation of average energy consumption is evaluated by formula:

$$
\overline{E n}=\sum_{i=1}^{k} R F A_{i} \cdot M E T_{i}
$$

where $\mathrm{k}-$ is the number of levels;

$\overline{E n}-$ is average energy consumption, $\mathrm{kcal} \mathrm{kg}-1$ per day;

RFA - is level of physical activity, c.u.;

MET - is weight coefficient.

Their physical working capacity was measured by means of Ruffier-Dickson test [12]. The analysis of mental working capacity was measured by the proof test of V. Ya. Anfimov [13]. Pupils need to cross out 2 given letters from the table within 4 minutes. The accuracy value of exercise execution is evaluated:

$$
\mathrm{A}=\mathrm{M} / \mathrm{N}
$$

where A - is accuracy value of exercise execution, c.u.; $\mathrm{M}$ - is quantity of cross out letters, pcs; $\mathrm{N}-$ is a total quantity of letters which needed to be cross out in the revised text, pcs. And coefficient of mental productivity is $\mathrm{P}=\mathrm{A} \cdot \mathrm{S}$,

where A - is accuracy value of exercise execution, c.u.; $\mathrm{S}$ - is number of revised letters.

We developed technology based on data analysis of scientifical and methodical literature and ascertaining experiment [14]. The technology is aimed at the development of professionally significant physical qualities (PSPQ) of future specialists of sewing industry. One of the technology's features is use of multimedia system (informationally-methodical system "Health brand-new”).

The diagram of the developed technology is provided on a figure 1.

The purposes of the developed technology are: development of professionally significant physical qualities; increase in level of theoretical knowledge; formation of positive motivation of pupils to physical culture classes; assistance in preparation of harmonically developed and highly qualified specialists.

Tasks of technology are: development and improvement of professionally significant physical

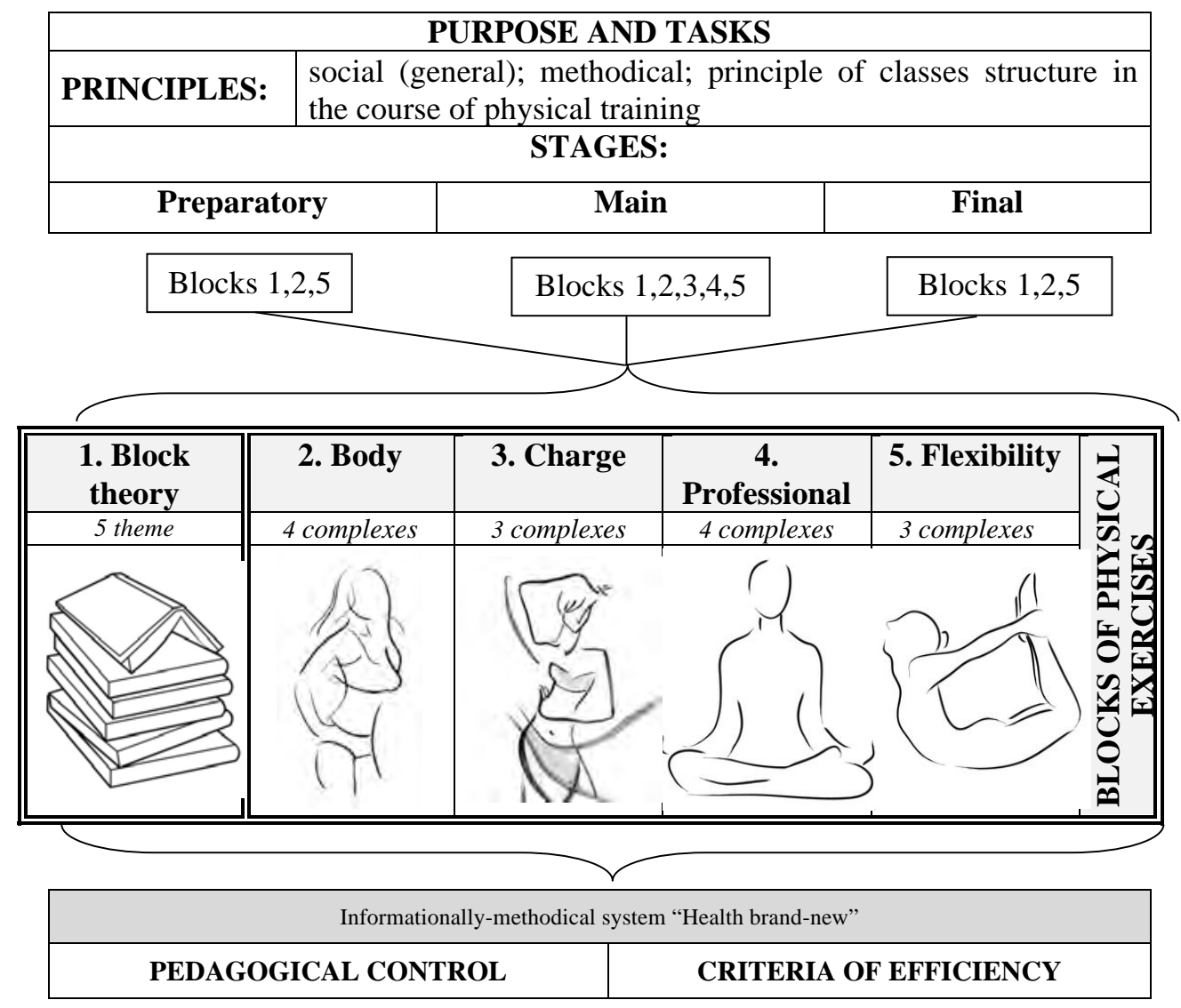

Fig. 1. The diagram of the technology aimed at the development of PSPQ of future specialists of sewing industry with use of information technologies. 
qualities of pupils; formation of knowledge and maintain of healthy lifestyle (HLS); formation of knowledge of professionally applied physical training and ability to apply it practically; formation of skills to independent training of physical exercises; increase in level of physical health of pupils and so forth.

The developed technology consists of the following principles: social, methodical and principles of classes' creation in the course of physical training [6].

We developed 4 blocks of physical exercises. Blocks included 14 different complexes for practical application in different parts of lessons. Recommended blocks of exercises were realized at different stages of technology implementation.

The developed technology included three stages of implementation:

$1^{\text {st }}$ stage -is preparatory, 16 lessons (September October). Principal tasks of stage are: interest formation of sewing industry pupils to the offered technology; development of the general physical fitness; acquisition of ability to development the professionally significant physical qualities (PSPQ); acquaintance of girl pupils with informationally-methodical system (IMC) "Health brand-new".

At the preparatory stage were applied the following blocks of exercises: "Body" and "Flexibility" and acquaintance with the block "Theory".

$2^{\text {nd }}$ stage - is the main, 48 lessons (November April). Task of the stag are: knowledge formation of physical culture; monitoring over girls' maintaining the healthy lifestyle principles (HLS); formation of skills to development the professionally significant physical qualities (PSPQ); acquisition of PAPT knowledge; formation of ability to apply it practically. At the main stage were applied exercises from the following blocks: "Body", "Flexibility" and study of block "Theory".

$3^{\text {rd }}$ stage - is final, 16 lessons (May - June). The main tasks of the final stage are formation of skills of PSPQ development and saving and improving of pupils' motivation to maintain HLS. At the final stage were

applied the following blocks of exercises "Body" and "Flexibility" and fixing of material from block "Theory" were applied.

The developed informationally-methodical system "Health brand-new" (fig. 2) [15] is a component of technology. The system is directed to increase in theoretical knowledge and practical skills in the course of PAPT of future specialists of sewing industry.

The informationally-methodical system (IMS) is interconnected set of means and methods which are used for: storage, processings and outputs of information; monitoring and correction of educational process.

During program developing process we considered principles of creation of electronic training programs [16], stages of pedagogical design [17] and ergonomic requirements to materials of electronic study [18].

IMS includes 4 blocks:

- block "Theory" contains information concerning bases of HLS and various modern forms of physical activity and so forth;

- block "Practical guidelines" includes 14 complexes of different physical exercises (formation of PAPT , prophylaxis of traumatism etc);

- block "Monitoring" provides individual registration to each pupil for passing theoretical testing or evaluation of physical state indicators. The database is formed for the teacher according to received information. The database allows to observe the dynamics of above-mentioned indicators;

- block "Bonus" includes videos about healthy lifestyle (HLS) and lessons of self massage, library of useful Internet resources devoted to HLS.

During introduction of technology were applied the following types of pedagogical control: previous, operative, current, total, self-checking.

Criteria of efficiency of the offered technology is the level of PSPQ development, level of mental working capacity, indicators of a physical state, level of theoretical readiness and motivation.

Statistical analysis. Statistical processing of research
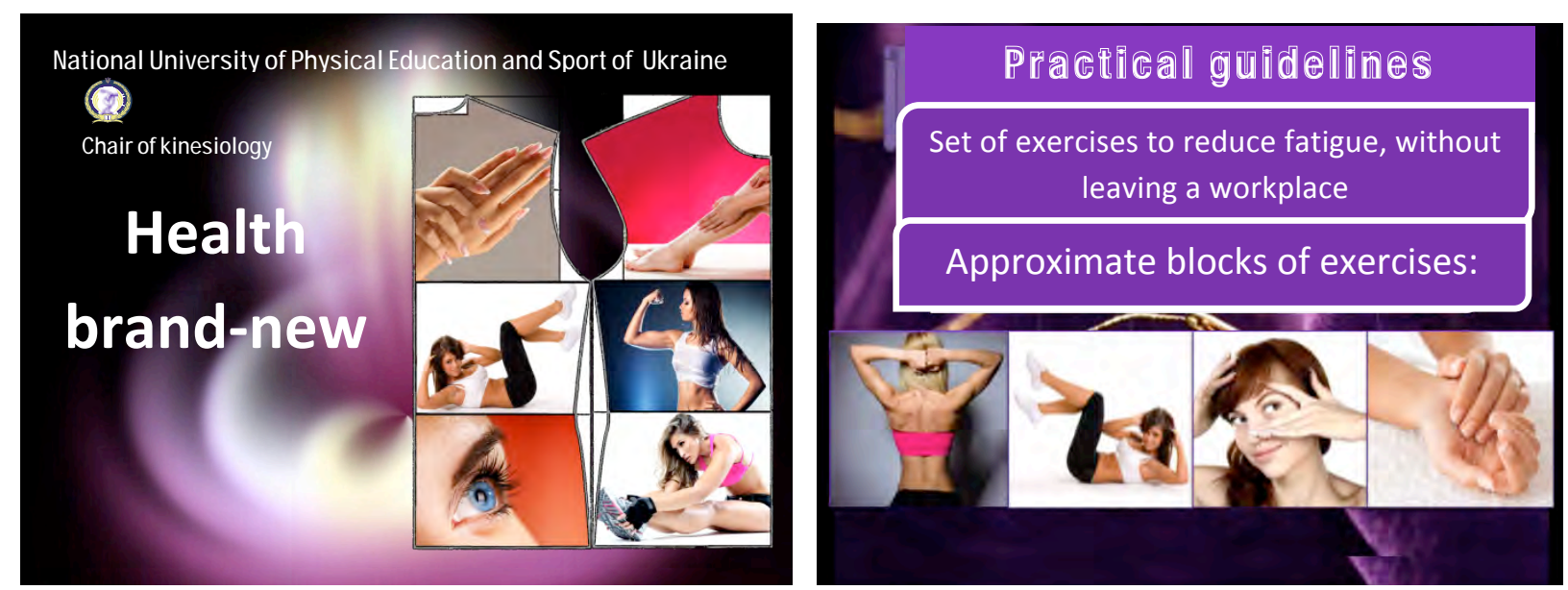

Fig. 2. Working windows of informationally-methodical system "Health brand-new" 
materials was conducted by means of Microsoft Excel 2010. The reliability of differences between indicators of samples (according to law of normal distribution of data) was checked by means of Student t-test. The reliability was considered as statistically significant at $p<0,05$.

\section{Results.}

Statistically significant increase in range of indicators are found in girls of EG: back muscles force increase by $25,85 \%$; the indicator of flexibility improved by $15,59 \%$; the general endurance improved by $8,30 \%$; coordination abilities improved by 7,63\%; $(\mathrm{p}<0,05)$. At the same time indicators of girls from CG changed statistically insignificant: ranging from $0,27 \%$ up to $1,86 \%(p>0,05)$.

Also levels of physical (fig. 3A) and mental (fig. 3B) working capacity considerably improved $(p<0,05)$ in EG. In CG augmentation was statistically insignificant ( $p$ $>0,05)$.

During the experiment took place positive changes in level of girls' physical activity in EG by 7,80\% (p < $0,05)$. In $C G$ took place positive changes of physical activity level by $0,53 \%(\mathrm{p}>0,05)$. After the experiment was carried out evaluation of theoretical knowledge level in subject "Physical education". It was determined the increase of indicator in girls of CG by 0,29 points ( $p>$
$0,05)$. In girls of EG was determined increase of indicator by 2,52 points $(p<0,05)$. Implementation of technology promoted increase in motivation of girls to physical culture classes: in representatives of EG - by $22,5 \%$ ( $p<$ $0,05)$. But in girls of $\mathrm{CG}$ the indicator decreased by $1,1 \%$ $(\mathrm{p}>0,05)$.

\section{Discussion.}

Our data added researches of other specialists [1, 2]. Authors specified the considerable influence of the professionally applied physical training (PAPT) on formation of the highly qualified specialist. So we expanded data of other research [2] in aspect of technical group of specialties. We detailed professionally applied physical qualities of future specialists of sewing industry taking into consideration the features of specialty. Our results confirm data of other scientists $[3,7,8]$ about efficiency of use of information technologies (IT) in the course of physical training. At the same time the majority of authors use IT developments only for increase in theoretical knowledge. Our development differs in opportunity to monitoring of theoretical knowledge and physical abilities, existence of video block for increase in motivation to classes.

In other research [5] it is offered to use the modern

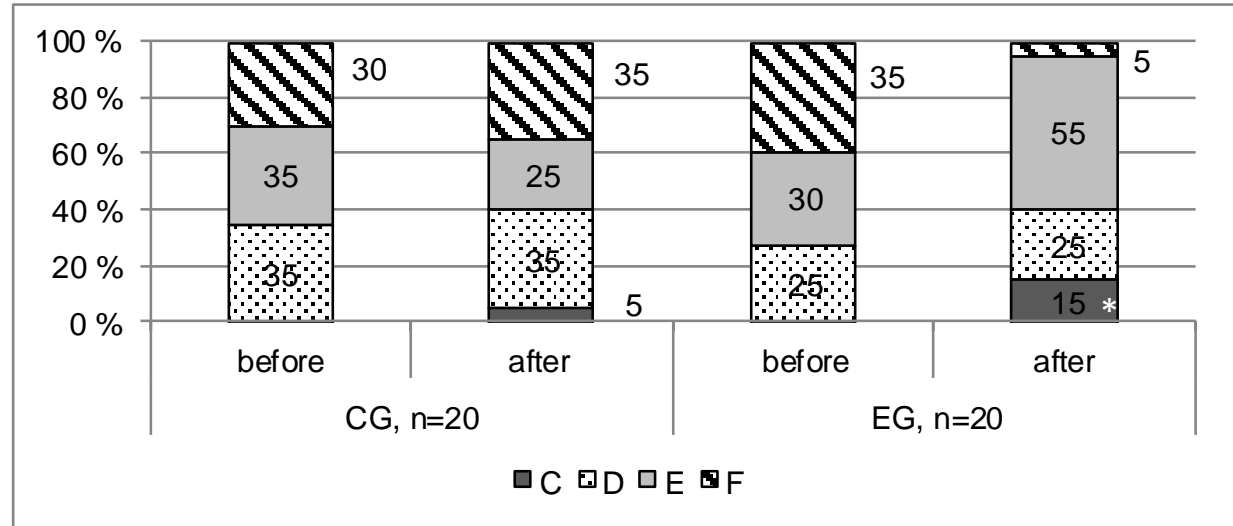

A) according to the level of physical working capacity

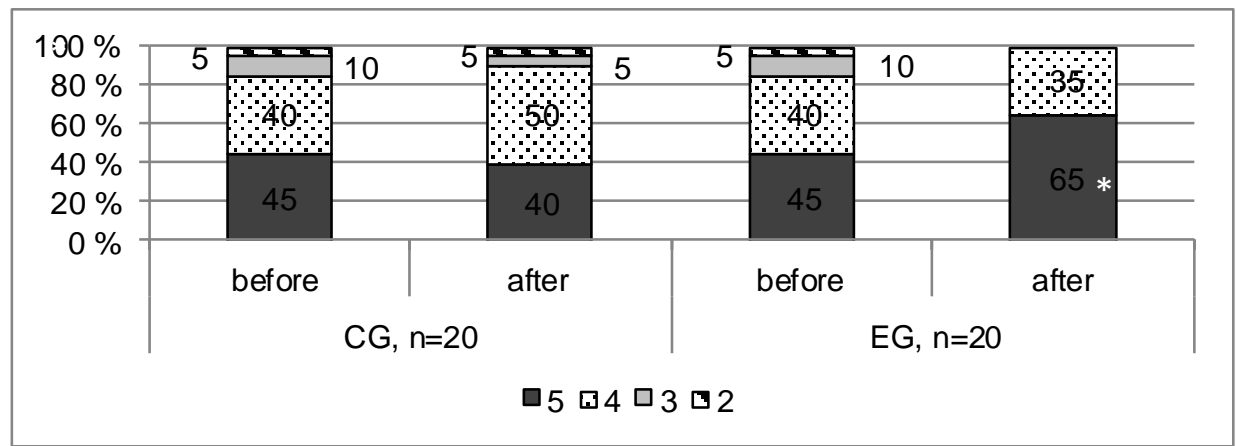

B) according to the level of mental working capacity

Fig. 3. Distribution of results of $C G$ and $E G$ before and after the experiment $(n=40)$ :

* - is statistically significant difference, $\mathrm{p}<0,05$; Assessment: C - high; D - good; E - average; F - satisfactory. CG control group; EG - experimental group. before - before the experiment; after - after the experiment. 5 - perfectly; 4 - well; 3 - satisfactorily; 2 - unsatisfactorily. $\%$ - the quantity of girls. 
types of gymnastics as means of increase in professional readiness of seamstresses. An algorithm of our technology is directed on development of physical qualities; formations of theoretical knowledge and motivation to lessons. The use of information and methodical system is also component of technology.

The pedagogical control has important role to increase classes' efficiency [19] which promotes optimization of physical activity [20]. Also important is formation of the students' positive attitude towards own health and way of life [21, 22]; self-checking of physical activities [23, 24]. In our research during introduction of technology were applied the following types of pedagogical control: previous, operative, current, total, self-checking. It is allowed to increase efficiency of physical training process of students.

\section{Conclusions}

The received results of researches confirmed efficiency of the developed technology. The technology is directed on: increase in professionally significant physical qualities of future specialists of sewing industry, motivation of pupils; formation of special skills. The received results, give the grounds to recommend it for use in the course of physical training in professional technical educational institutions.

\section{Financing}

The research has been fulfilled in compliance with Combined plan of SRW in sphere of physical culture and sports for 2011-2015 on the topic 3.7 "Perfection of biomechanical technologies in physical education and rehabilitation taking into account individual characteristics of human motor skills" (state registration number 0111U001734). In 2016-2017 researches has been fulfilled in compliance with the plan for research work of the National University of Physical Education and Sports of Ukraine on the topic 3.13 "Theoretical and methodological foundations of health forming technologies in the process of physical education of various population groups" (state registration number 0116U001615).

\section{Conflict of interests}

The authors declare that there is no conflict of interests.

\section{References}

1. Docenko IuA. Evaluation of the psychophysical readiness for work of students of mining universities. Cand. Diss., Kiev: NUPES; 2014. (in Ukrainian)

2. Pilipej LP. Theoretical and methodical foundation for professionally-applied physical training of tertiary level students. Dokt. Diss., Kiev: NUPES; 2011. (in Ukrainian)

3. Kashuba VA, Dudko MV, Martyniuk OA. Information and communication vector in the process of training health and fitness. Molodij vchenij, 2017; 3(1):151-155. (in Ukrainian)

4. Waterson Patrick. Health information technology and sociotechnical systems: A progress report on recent developments within the UK National Health Service (NHS). Applied Ergonomics, 2014; 45(2):150-161.

5. Ajziatullova GR. Modern types of gymnastics as means of increase in professional readiness of future operator of the sewing equipment. Cand. Diss., Sankt Petersburg; 2006. (in Russian)

6. Krucevich TIu. Theory and technique of physical training. Kiev: Olympic Literature; 2003. (in Ukrainian)

7. Kashuba V, Futornij S. Iз досвіду використання інформаційних технологій у процесі занять фізичним вихованням різних груп населення. Molodizhnij naukovij visnik, 2016; 21: 81-90. (in Ukrainian)

8. Kashuba VA, Maslova EV, Rychok TN, Lopackij SV. Using multimedia technology in physical education of different population. Naukovo-pedagogichni problemi fizichnoi kul'turi, 2017; 6 (88):37-41. (in Ukrainian)

9. Futornyj SM, Dudko MV. Healthy lifestyle students in physical education: state of the issue and solutions. Nauka i sport: sovremennye tendencii, 2015; 8(3): 98-109. (in Ukrainian)

10.Physical culture. Program for professional educational institutions [Internet]. 2017 [updated 2017 Feb 10; cited 2017 Apr 10]. Available from: http://dptnz-vpal.org.ua/ navchaln-programi/31-fzichna-kultura-programa-dlya-ptnz. html (in Ukrainian)

11.Davidenko EV, Masaul R. Technique of a Fremingemsky study of physical activity of the person: recommendations about use. Kiev: Olympic Literature; 1999. (in Ukrainian)

12.Angeline Nsenga Leunkeu, Roy J. Shephard, Said Ahmaidi. Historical Perspective. A brief history of exercise clearance and prescription: 1.The era of heart rate recovery curves. Health \& Fitness Journal of Canada, 2014;7(1):26-35.

13.Falova OE. Collection of practical works on the course «Human physiology»..Ulyanovsk: U1STU; 2007. (in Russian)

14.Golovanova $\mathrm{N}$. To the question about motivation inducing young students to engage in physical culture and sports. Molodizhnij naukovij visnik, 2014; 16: 48-51. (in Ukrainian)

15.Kashuba VA, Futornyj SM, Golovanova NL. By the use of information technology in physical education students. Slobozhans'kij naukovo-sportivnij visnik, 2011; 4: 157-163. (in Ukrainian)

16.Botia MV, Sejfetdinov MR. The electronic textbook the general principles and a technique of construction [Internet]. 2017 [updated 2017 Feb 10; cited 2017 Apr 10]. Available from: http://iiidudsu.ru/index.php?option=com content\&task=view\&id (in Russian)

17.Kriukova NL. Use of methods of pedagogical design during creation of the electronic and methodical complex «Network Technologies and Web Design at School» [Internet]. 2017 [updated 2017 Feb 10; cited 2017 Apr 10]. Available from: http://festial.1september.ru/articles/516158/ (in Russian)

18.Solovov AV. Electronic training. Perspective, dynamics, technology. Samara: New equipment; 2006. (in Russian)

19.Kriventsova I, Pashkevych S, Iermakov S, Bartík P, Michal J, Nosko M, Yermakova T. Fitness - aerobic training of 15 - 17 years' age girl students, who have significant risk of deviations in backbone functional state. Journal of Human Sport and Exercise, 2017;12(4), 1289-1297. doi:10.14198/ jhse.2017.124.15

20.Straczynska A, Kruczynski J, Radziminska A, Weber-Rajek M, Lulinska-Kuklik E, Goch A. The positive role of kinesio taping in adjunctive therapy of static plano-valgus feet in children between the ages of 5 and 7. Baltic Journal of Health and Physical Activity. 2017;9(2):89-97. 
21.Kalina RM, Jagiello W, Chodala A. The result of "testing fights in a vertical posture" as a criterion of talent for combat sports and self-defence - secondary validation (part II: the accuracy). Archives of Budo Science of Martial Arts and Extreme Sports. 2016;12.

22. Weber-Rajek M, Radziminska A, Slominski K, LulinskaKuklik E. Evaluation of the Effectivenness of Sonotherapy in the Treatment of Chronic Pain Syndromes of the Lumbosacral Spine - Pilot Study. Acta Balneologica. 2017;59(2):104-110.

23.Kozina Z, Iermakov S, Bartík P, Yermakova T, Michal J. Influence of self-regulation psychological and physical means on aged people's functional state. Journal of Human Sport and Exercise, 2018;13. doi:10.14198/jhse.2018.131.10

24.Jagiełło M, Iermakov SS, Nowiński M. Differentiation of the somatic composition of students physical education specialising in various sports. Archives of Budo Science of Martial Arts and Extreme Sports. 2017;13:63-70.

25.Jagiello W, Sawczyn S, Jagiello M. The subjective profile of positive health and survival abilities in women differing as to physical activity. Archives of Budo, 2012;8(4):219-224.

26.Podrigalo LV, Iermakov SS, Jagiello W. Special indices of body composition as a criterion of somatic development of martial arts practitioners. Archives of Budo Science of Martial Arts and Extreme Sports, 2017;13:5-12.

\section{Information about the authors:}

Kashuba V.O.; http://orcid.org/0000-0001-6669-738X; kashubavo@gmail.com; Department of Biomechanics and Sports Metrology, National University of Physical Education and Sport of Ukraine; Fizkulture str., 1, Kiev, 03680, Ukraine.

Golovanova N.L. (Corresponding author); http://orcid.org/0000-0002-8837-7501; ngolovanova100@gmail.com; Department of Innovation and Information Technologies in Physical Culture and Sports, National University of Physical Education and Sport of Ukraine; Fizkulture str., 1, Kiev, 03680, Ukraine.

Cite this article as: Kashuba VO, Golovanova NL. Increase in efficiency of professionally applied physical training of pupils of 16-17 years old based on application of informational and methodical systems. Physical education of students, 2018;22(2):57-62. doi:10.15561/20755279.2018.0201

The electronic version of this article is the complete one and can be found online at: http://www.sportedu.org.ua/index.php/PES/issue/archive

This is an Open Access article distributed under the terms of the Creative Commons Attribution License, which permits unrestricted use, distribution, and reproduction in any medium, provided the original work is properly cited (http://creativecommons.org/licenses/by/4.0/deed.en).

Received: 29.12.2017

Accepted: 19.01.2018; Published: 27.04.2018 